\title{
Nurture the nature: A preliminary study of the musical practices of two European peripatetic communities
}

This paper, as a preliminary study, will focus on the musical activities of two distinct European peripatetic groups - the Hungarian Rom Gypsies and the Irish Travellers, bringing in references to the Travellers of British Isles when appropriate - to examine the extent their similarities in their musical practices result from shared socio-cultural features and values that derive from the specificities of their nomadic life-styles. Whilst there is considerable data on the musical activities of various Rom Gypsy communities throughout Europe, research into the musical life of the Irish Travellers is rather limited, consisting primarily of collections of ballads and lyrical songs. Nevertheless, this material provides clear indications that musical practices observed amongst the Rom are also present amongst Irish Travellers, even though the music itself sounds completely different. One of the main features shared by the Gypsy and Traveller communities is that they both adopt the musical repertoire of the host society in which they live. This material is then altered in performance by both Gypsies and Travellers, to distinguish them as a unique social group. This paper will illustrate some of these processes of appropriation and adaptation of local repertoires, in an attempt to detect similar patterns which articulate with a nomadic ethos, the pivotal node in the construction and realisation of Gypsy-Traveller identity.

\section{Background}

The ethnomusicological emphasis upon the ethnography of musical performance emerged in the late 1970s (McLeod \& Herndon 1980, Blacking 1981, Seeger 1987), under the influence of various related disciplines, such as socio-linguistic (Hymes 1964) and contextual folklore studies (Baumann 1978). This shifted the analytical gaze away from the study of musical styles and genres as 'texts' to the study of musicmaking as a mode of communication and sociability. In this process, musical material or the musical product - has become secondary to discerning the more fundamental processes which people use to construct musical meaning within specific contextual settings. A new concern, dealing with such issues as 'by whom to whom', 'where and when', 'why and how', has taken precedence over 'what' people perform. This approach provides a means of examining how musical meanings are constructed and negotiated in real processes of musical interaction.

Up until now cross-cultural comparisons in ethnomusicology have focused upon surface-level similarities in the musical sounds of different traditions, such as their melodic patterns, intervallic characteristics, ensemble organisation etc., an approach 
epitomised by Lomax's (1968) cantometrics project. Such comparisons, however, can be highly misleading as "two cultures may appear to employ the same scale structure, but this structure might be interpreted differently by the members of each culture. Conversely, the music of two cultures may employ very different materials, but the underlying mechanism governing the organisation of these materials might be the same for both" (Meyer 1960:50). Thus, ethnomusicologists have begun to search for crosscultural parallels in processes of musical performance, such as the modes of sociability that can be enacted in performance, as suggested by Reily (1997), or the participatory effects of temporal and tonal discrepancies, as discussed by Kiel (1994:96-108).

Any comparison of musical systems across cultural boundaries, however, must also account for the multiplicity of musical meanings that people find in them. This project will integrate the construction of musical meanings articulated through the particular performance practices of the Gypsy and Traveller communities, relating them to the socio-cultural values and life-styles of these two peripatetic communities. Ultimately it should reveal how a similar ethos can generate both similar and dissimilar performance practices, which nonetheless cohere with the discourses with which they articulate.

\section{Historical context}

Rom Gypsies first appeared in Eastern Europe in the late 14th century, reaching the West by the early 15 th century, where they met and mixed with various indigenous nomadic populations. The emergence of nation-states and colonialism in Western Europe marked a change in attitude toward peripatetic groups, and in most Western countries strict and drastic legislation was imposed to stop the entrance of migrants and to inhibit itinerant life-styles (Acton 1994). In Eastern Europe, however, labour shortages in agriculture and in the military prompted the formulation of policies aimed at attracting the Gypsy population through both voluntary and forceful means. Under these diverse influences, Gypsies were transformed into numerous distinct cultural groups. By the 20th century, they constituted a number of cultural sub-groups which spoke different languages, practiced different religions and played a great variety of different musics.

The presence of peripatetic groups in society led to the formulation of discourses embodying the dominant society's attitudes toward their life-styles. Two major attitudes predominated: they were either united under the negative all-embracing category of 'dangerous vagabonds' (Fraser 1992:116), or they were divided into 'real' and 'notreal' Gypsies. While 'real' Gypsies embodied the fascinating, exotic, colourful 'other', the 'not-real' Gypsies came to be seen as lazy, drop-out deviants (Okely 1994:6). In Hungary, for example, lenient attitudes toward Gypsies - most of whom were of Rom extraction - allowed them to practice their traditional skills, and in time they became a seemingly 'assimilated' part of the society, including in their ranks numerous celebrated musician and composer of the newly created 'Hungarian national music'. The second wave of Gypsy migrants, however, the Vlach Rom, who entered Hungry in the mid 19 th century, experienced a far less welcoming reception. With their Balkan-influenced traditions and Romany language, Vlach Gypsies came to embody the stereotype of the 'strange', the 'deviant' and the 'primitive'. In Britain, where the Rom embodied the exotic, the indigenous Traveller groups were left to carry the negative association attached to a non-conformists itinerant life-style in an increasingly puritanical and 
work-ethic oriented Victorian society. The position of the Irish Travellers offers yet another variant, which is intimately linked to the English colonialism of Ireland (Okely 1994:4)). Here Irish Travellers chose to emphasise their historic links with the Irish, thereby avoiding any associations with the 'foreigners' (i.e., the English).

The political positions taken in both Hungary and Ireland influenced music and social science research amongst Gypsies and Travellers in a somewhat similar fashion. In their struggle for freedom and national identity music researchers focused on what they considered to be their 'own' music, delaying systematic research into the music of the peripatetic groups within their territories. In Hungary serious research into Gypsy music did not begin until the 1950s, whilst in Ireland it was only initiated in the 1970s. At that time the first anthropological research of the Irish Travellers commenced (Gmelch 1975), followed a decade later in Hungary (Stewart 1987). It is only now that there is sufficient data on both communities to allow for significant comparative research to be undertaken.

\section{Core features of Gypsy-Traveller culture}

From anthropological research on Gypsies the following aspects have emerged to be common among the various European Roma and Traveller groups:

1. Gypsies and Travellers belong to a larger category of peripatetic groups (Rao 1987) that form small cognatic and affinal family units with some unrelated families. Over the last century some groups have become sedetarised, but the ethos of their former nomadic life-styles has been retained, marking their world view (McDonagh 1994), which simultaneously a 'global' and a 'temporary' local identity (Kertész Wilkinson 1996:229). It is important to stress that nomadism, as an important part of the Gypsy ethos, has to be understood "not in the usual dictionary sense of nomads as people who are continually on the move from place to place" (Liégeois 1986:50) but an ideology and a belief system (Okely 1983:77-104) that exists regardless of whether a group is still largely itinerant, seasonally nomadic or has chosen, or been forced into, sedentarism.

2. The nomadic ethos favours minimal possessions, so surplus is invested in items that can be easily moved and sold, such as jewellery (McDonagh 1994:99), or in goods that are useful to the itinerant life-style, such as horses and, more recently, cars (Okely 1983:145). Thus, Gypsies and Travellers hold very different attitudes towards money, property and possessions from those of the settled and dominant society. Peripatetic communities emphasise sharing and reciprocity as core social values, rather than values geared toward increasing personal and inherited prosperity (Stewart 1997:8889).

3. Economically Gypsy and Traveller communities have an inter-dependent relationship with the host society, offering skills and services which the dominant society regards as dirty, non-prestigious and/or badly paid or lucrative jobs which requires fast adoptations but these occupations allow Gypsies and Travellers to work independently in non-waged labour (Okely 1983:53-56).

4. Despite this economic inter-dependency and the continues pressures exerted on 
peripatetic communities to assimilate into the dominant society, they have managed to preserve their autonomy. Through their purity systems, they create and sustain boundaries between themselves and the settled population, systems which also operate within peripatetic communities in the construction of boundaries between Travellers and Gypsies, different families units, economic groups, gender categories and generational sub-groups. The human body, which is divided into clean and defiled parts, serves as the basis for purity concepts. This metaphor is extended to encompass the natural and supernatural surroundings, regulating actions and emotions (Douglas 1966, Okely 1983:77-104). Gypsy and Traveller groups apply these regulations in a diverse and flexible manner, enabling them to adapt to changes whilst preserving their separateness from the dominant cultures that surround them. In many instances, the prejudices of the dominant society strengthen the boundaries marking Gypsy and Traveller groups, making them almost impossible to cross even if the members of peripatetic groups were inclined to do so (Mirga 1987:253).

5. Without land of their own and a rather bleak past history, the social memory of Gypsies and Travellers tends to concentrate on the experiences of the three living generations, whilst events outside living memory become integrated into a repertoire of shared myths, folk stories, proverbs and other forms of verbal art. Their social memory favours the preservation of happy events, whilst unhappy experiences are either retained as personal history or as an expression of non-specific, widely shared human experiences of sorrow, grief and loneliness. This attitude is a parallel at the psychological level of their orientation toward non-possession and the ideal of 'travelling light' (N’ Shœin $¥ r$ 1994:60).

\section{Some shared characteristics in the musical practices of Hungarian Roma and British Traveller communities}

There are two main type of performance contexts for Gypsy and Traveller communities: 1) musical performances oriented toward the musical needs of outsiders and 2) musical performances oriented toward the in-group. Some groups participate in both types of performance context, whilst others perform only for the in-group. For centuries the Hungarian Romungro Gypsies have performed for the dominant society, where their musical activities have been primarily instrumental (Sárosi 1978). Whilst they also perform for the in-group, their in-group musical practices have only recently been documented (Lange 1993). Among the Hungarian Vlach Gypsies, musical practices are primarily vocal and oriented toward in-group performance (Kovalcsik 1987:45, Kertész Wilkinson 1998:118), though this has been changing over the last few decades with the emergence of a few professional Vlach Gypsy bands. For the most part the Romungro perform Hungarian popular music mixed with a number of popular international pieces on their traditional instruments, configured as a violin-viola-double bass string band with an additional clarinet and cimbalom. The Vlach Gypsies have developed a unique musical tradition which draws on Hungarian and Balkan musical styles (Hajdú 1958:17). They sing a number of Hungarian songs alongside adapted Rom songs from the surrounding culture, and they have recently incorporated materials from the Balkan and Mediterranean regions. In the last three decades they have started taking up instruments, including various types of lutes, double bass and traditional percussion in the form of water cans, chairs and other household items. Because Eastern Europe 
remained agricultural well into the 20th century, Gypsies still play an important role in communal celebrations, both in rural and urban settings (Sárosi 1978, Rice 1994:2930, Manuel 1988:121-7). Nevertheless, they have a low social status, which corresponds both with their ethnic origin and marginalised position in society and with the ambiguous attitudes of the dominant culture towards music and musicians (Merriam 1964:140, Baumann 1978:45). Currently in Britain it is possible to hear recently formed professional Scottish Traveller singers (MacColl and Seeger 1986, Munro 1984:205-32 ), but Gypsy and Traveller musicians were known to have played for outsiders in the early part of 19th century, when "feasts, fairs, wakes and weddings formed a central feature of rural social life" (Mayall 1988:55).

Musicians working professionally and semi-professionally need to adapt their musical material to the requirements of their audiences; yet among Gypsies and Travellers adaptations are also a typical feature of in-group music-making (Kennedy 1975:747, Court 1985:49, Munnelly 1975:3-5, Carroll 1975:31-35, MacColl and Seeger 1977, 1986). In her discussion of the Irish Traveller repertoire, Court implied that they adopted their material more or less at random, performing anything from "from Irish and English ballads, bawdy music hall songs,...to American commercial love songs and Country and Western" (Court 1985:49). Closer investigation, however, reveals that their songs express Traveller sentiments, just as Hungarian Vlach Gypsy songs, be it at a communal or a personal level (Kertész Wilkinson 1996:225-33, Carroll $1975: 31-32)$. It is also important to note that the performers themselves distinguish between the various genres in their repertoire (Kertész Wilkinson 1998:118-21). As Carroll (1975:34) reported, this may even be demonstrated in performance, as an Irish Traveller did when he delivered the song 'Barabara Allen' once in the traditional style and then in the country-western style.

For Gypsy and Traveller communities the transformations they impose on the musical materials they appropriate constitute a primary means of expressing the uniqueness of their identity. Commonly they either add or subtract musical sections to achieve various ends: the addition or suppression of verses, words or phrases may be used to mark the mood of the performer or to accommodate the melodic structure (Kertész Wilkinson 1994, Munnelly 1975:7); the melodic structure may be altered, such that some lines are left out while others are repeated, as reported by Shield (1993:114) amongst Irish Travellers. Temporal alterations are also common to both groups; these may be very idiosyncratic (Kertész Wilkinson 1990a:193-202, 1998:16570 , alternating between accelerated virtuosic displays to extremely slow deliveries (Kennedy 1975:746, Kertész Wilkinson 1994:143-290). The textual alterations of the Irish Travellers, as reported by Munnelly (1975:14), often dismember the existing poetic rhyme scheme (Munelly 1975:8); such textual alterations often blur meanings both amongst the Hungarian Rom Gypsies (Kertész Wilkinson 1992:115) the Irish Travellers (Kennedy 1975:747).

Important performance stylistics involve the use of particular vocal timbres, which again mark differences between Gypsy and Traveller communities and the dominant population. In Hungary such markers include the use of 'thick' voices for women and either 'course, deep or high' voices for men (Kertész Wilkinson 1998:123), whilst in Ireland the 'high-pitched and nasal' vocal qualities of the Travellers are very different from the "more intimate, heavily ornamental style fleuri common in the Irish language Sean-Nós singing" (Munnelly 1975:6). Phrase endings in Hungary typically involve strong final tones that are emphasised by pauses before they are emitted, whereas Irish Travellers employ a "glottal stopping, a kind of audible punctuation" (Munnelly 1975:7), to end their phrases. 
An intense emotional involvement with the performance is also typical for both the Gypsies and the Travellers. Though crying during performance is avoided in Hungary to prevent the 'heart from breaking', singing is aimed at moving the audience (Kertész Wilkinson 1994), amongst the Irish Travellers, however, some are often moved to tears through particular song (Munnelly 1975:14). It is typical in men's performances amongst Scottish Travellers performances can provoke tears among men through the associations they elicit of those absent at the event, whilst women weep over sentiments expressed in the words of the songs themselves (Munro 1984:204). Alterations may take place because of the intentionality of the singer (Porter 1974:7-26), as the songs move from a general message to a personal one (Kertész Wilkinson 1992:115), suggesting that the importance of 'truth' (Stewart 1989: 86-87, 91-98) among the Vlachs, referred to as 'real' among the English Travellers (Willy Guy pers. comm.), is yet another feature common to both Gypsy and Traveller performance practices.

Gypsies and Travellers are also unique in that they are carriers of both old and new traditions, performing songs and other forms of verbal art that have been discarded by the host populations whilst also appropriating the latest hits of the world-music repertoire. This approach to repertoire is pregnant with meaning, expressing simultaneously their similarities and differences in relation to the dominant society whilst also affirming their global citizenship.

\section{Summary}

It is expected that the following aspects will be found shared between two Gypsy groups:

1. The Roma and Irish Travellers select musical materials and styles from the dominant cultures, upon which they impose transformations coherent with their ethos.

2. Distinct elements of Gypsy and Traveller aesthetics are superimposed on the local musical styles as a means of marking boundaries between the particular community and the host society.

3. The transformations are aimed at demonstrating musical virtuosity and/or expressing intense emotions.

4. The musical items (the songs) acquire strong associations with particular people, which allow them to articulate inter-personal relations within the particular community.

5. Clear distinctions are made between musical expression and ordinary speech, in which musical performance is seen to be an expression of the 'real' and the 'true'. 6. Musical traditions articulate within a particular community with other expressive forms (verbal arts, dance, material culture, spatial organisation etc.) in the construction of Gypsy and Traveller identity.

7. Through their musical performance practices, Gypsies and Travellers articulate a concept of global citizenship which simultaneously affirms their unique ethnic identity and their relation to the host society.

Without doubt, there are numerous aspects of Gypsy and Traveller musical performance awaiting further and deeper examination; but the inventory of parallels discussed in this paper provides clear indications that many of the shared expressive devices in the performance practices of Gypsy and Traveller communities can be 
linked to their common values based on the specificities of a nomadic ethos.

\section{Acknowledgments}

The fieldwork in Hungary was carried out with financial assistance from The British Council and the University of London Central Research Fund. My Ph.D. studies during 1988-91 were supported by a grant from The British Academy.

I would also like to express my gratitude to Dr.Suzel Reily, Queens' University, Belfast, for her editing comments.

\section{Bibliography}

Acton, Thomas 1994. Categorising Irish Travellers. In Irish Travellers. Culture and Ethnicity eds. M McCann, S O Siócháin and J Ruane. Belfast: Institute of Irish Studies, the Queens University of Belfast.

Bauman, Richard 1978. Verbal Art as Performance. Rowley, Massachusetts: Newbury House Publishers.

Blacking, John 1981. Ethnography of Musical Performance. In Report of the Twelfth Congress, Berkeley 1977 eds. D Heartz and B Wade. Kassel: Bärenreiter. Pp 383-401.

Carroll, Jim 1975. Irish Travellers around London, Folk Music Journal, 3(1): 31-41. Court, Artella 1985. Puck of the Droms. The Lives \& Literature of the Irish Tinkers. Berkeley, London: University of California Press.

Douglas, Mary 1966. Purity and Danger. New York: Praeger.

Fraser, Angus 1992. The Gypsies Oxford: Blackwell Publishers.

Gmelch, Sharon 1975. Tinkers and Travellers. Dublin: O'Brien Press.

Hajdú, André 1958. Les Tsiganes de Hongroi et leur Musiques. Etudes Tsiganes, $4(1): 4-28$.

Hymes, Dell (ed.) 1964. Language in Culture and Society: A Reader in Linguistics and Anthropology. London: Harper and Row.

Keil, Charles 1994. Participatory Discrepancies and the Power of Music. In Music Grooves by C Keil and S Feld. Chicago and London: The University of Chicago Press.

Kennedy, Peter 1975. Folk Songs of Britain and Ireland. London: Cassell.

Kertész Wilkinson, Irén 1990a. 'Lokes Phen!' An Investigation into the Musical Tempo Feeling of a Hungarian Vlach Gypsy Community based on their own Evaluation, 100 Years of Gypsy Studies ed. M Salo. Cheverly, Maryland. Pp. 193-202.

Kertész Wilkinson, Irén 1990b. Musical Tests Among Hungarian Vlach Gypsies. In VII European Seminar in Ethnomusicology. Pre-publication of conference papers eds. Baumann, Günther, de Oliviera Pinto and Simon,. Berlin: Abteilung Musikethnologie Museum für Völkerkunde SMPK. Pp. 299-308.

Kertész Wilkinson, Irén 1992. Genuine and Adopted Songs in the Vlach Gypsy Repertoire: A Controversy Re-examined." British Journal of Ethnomusicology, 1:111-136.

Kertész Wilkinson, Irén 1994. Diversity in Unity. A study of Individual Creativity through the Performance of Songs among the Vlach Gypsies of South-eastern 
Hungary." PhD Thesis, University of London, Goldsmiths College.

Kertész Wilkinson, Irén 1996. Differences Among One's Own and Similarities with the Other: Dual Role of Adopted Songs and Texts Among the Hungarian Vlach Gypsies. In Echo der Vielfalt [Echoes of Diversity], ed. U Hemetek. Vienna: Böhlau-Verlag. Pp 225-233.

Kertész Wilkinson, Irén 1997. Musical Performance: a Model for Social Interaction between Vlach Gypsies in South-eastern Hungary. In Gypsy Culture and Gypsy Identity eds.T Acton and G Mundy, eds. Hatfield: University of Hertfordshire Press. Pp 97-126.

Kertész Wilkinson, Irén 1988. The Fair is ahead of me. Individual creativity and social contexts in the performances of a south-east Hungarian Vlach Gypsy slow song. Budapest: Hungarian Academy of Sciences.

Kovalcisk, Katalin 1987. Popular Dance Music Elements in Gypsy Folk Music, Popular Music 7: 45-65.

Lange, Rose Barbara 1993. Holy Brotherhood: The Negotiation of Musical Style in a Gypsy and Magyar Pentecostal Church. PhD Thesis, University of Washington.

Manuel, Peter 1988. Popular Musics of the Non-Western World: An Introductory Survey. New York: Oxford.

Mayall, David 1988. Gypsy-Travellers in Nineteenth-century Society. Cambridge: Cambridge University Press.

MacColl, Ewan and Peggy Seeger 1977. Travellers' Songs from England and Scotland. London: Routladge and Kegan Paul.

MacColl, Ewan and Peggy Seeger 1986. Till Doomsday in the Afternoon. The Folklore of a Family of Scots Travellers, the Stewarts of Blairgowrie. Manchester: Manchester University Press.

McDonagh, Michael 1994. Nomadism in Irish Travellers' Identity. In Irish Travellers. Culture and Ethnicity. eds.M McCann, S Ó Siócháin and J Ruane. Belfast: Institute of Irish Studies, The Queens University of Belfast. Pp. 95-109.

McLeod, Norma and Marcia Herndon (eds.) 1980. The Ethnography of Musical Performance. Norwood, Penn.: Norwood Editions.

Merriam, Alan 1964. The Anthropology of Music. Evanston, Ill.:Northwestern University Press.

Meyer, Leonard B. 1960. Universalism and Relativism in the Study of Ethnic Music, Ethnomusicology. 4: 49-54.

Mirga, Andzrej 1987. The Category of 'Romanipen' and the Ethnic Boundaries of Gypsies. Ethnologia Polona 13: 243-255.

Munnelly, Tom 1975. The Singing Tradition of Irish Travellers, Folk Music Journal 3 (1): 3-30.

Munnelly, Tom 1983. Songs of the Irish Travellers 1967-75. Dublin: Trinity College, European Ethnic Oral Traditions.

Munro, Ailie 1984. The Folk Music Revival in Scotland. London: Kahn-Averill.

Ní Shúinár, Sinéad 1994. Irish Travellers, Ethnicity and the Origins Questions. In Irish Travellers. Culture and Ethnicity, eds. M McCann, S O Siócháin and J Ruane. Belfast: Institute of Irish Studies, the Queens University. Pp 54-77. Okely, Judith 1983. The Traveller Gypsies . Cambridge: Cambridge University Press.

Okely, Judith 1994. An Anthropological Perspective of Irish Travellers. In Irish Travellers. Culture and Ethnicity eds. M McCann, S Ó Siócháin and J Ruane. Belfast: Institute of Irish Studies, The Queens University. Pp 1-19. 
Porter, James 1974. Jeannie Robertson's 'My Son David': A Conceptual Performance Model, Journal of American Folklore, 89: 7-26.

Rao, Aparna 1987. The Other Nomads: Peripatetic Minorities in Cross-Cultural Perspective. Cologne and Vienna: Böhlau Verlag.

Reily, Suzel 1997. Folia Rehearsals: Music-Making and Sociability. Paper presented in the Ethnomusicology Seminar Series, The Queen's University Belfast.

Rice, Timothy 1994. May It Fill your Soul: Experiencing Bulgarian Music. Chicago: University of Chicago Press.

Sárosi, Bálint 1978. Gypsy Music. Budapest: Corvina Press.

Seeger, Antony 1987. Why Suya Sing? A musical anthropology of an Amazonian people. Cambridge: Cambridge University Press.

Shields, Hugh 1993. Narrative Singing in Ireland. Lays, Ballads, Come-all-yes and Other Songs. Dublin: Colour Books.

Stewart, Michael 1987. Brothers in Song: The Persistence of (Vlach) Gypsy Identity and Community in Socialist Hungary. Ph.D. Dissertation. Faculty of Economics, London School of Economic and Political Science.

Stewart, Michael 1989. 'True Speech': Songs and Moral Order of a Hungarian Vlach Gypsy Community, Man 24(1): 79-101.

Stewart, Michael 1997. The Puzzle of Roma Persistance: Group Identity without a Nation. In Gypsy Culture and Gypsy identity eds. T Acton and G Mundy. Hatfield: University of Hertfordshire Press. Pp 82-96. 